\title{
$\mathrm{FBG}$ 센서를 이용한 강연선 전달길이 측정
}

\author{
이 성 철 ${ }^{1} \cdot$ 최 송 이 $^{2} \cdot$ 신 경 준 $^{3} \cdot$ 김 재 민 $^{2} \cdot$ 이 환 우 ${ }^{4}$ \\ ${ }^{1}$ 국제원자력대학원대학교 원자력산업학과, ${ }^{2}$ 전남대학교 해양토목공학과, ${ }^{3}$ 충남대학교 토목공학과, ${ }^{4}$ 부경대학교 토목공학과

\section{Measurement of Transfer Length for a Seven-Wire Strand with FBG Sensors}

\author{
Seong-Cheol Lee, Song-Yi Choi ${ }^{2}$, Kyung-Joon Shin ${ }^{3}$, Jae-Min Kim ${ }^{2}$ and Hwan-Woo Lee ${ }^{4+}$ \\ ${ }^{1}$ Department of NPP Engineering, KEPCO International Nuclear Graduate School, Ulsan, 45014, Korea \\ ${ }^{2}$ Department of Marine and Civil Engineering, Chonnam National Univ., Yeosu, 59626, Korea \\ ${ }^{3}$ Department of Civil Engineering, Chungnam National Univ., Daejeon 34134, Korea \\ ${ }^{4}$ Department of Civil Engineering, Pukyung National Univ., Pusan, 48513, Korea
}

\begin{abstract}
In this paper, an experimental program has been conducted to investigate transfer length in high strength concrete members pretensioned through a seven-wire strand with FBG sensors. To measure transfer length, five members were fabricated, which had a length of $3 \mathrm{~m}$ and a cross-section of $150 \times 150 \mathrm{~mm}$. It was measured that the concrete compressive strength was $58 \mathrm{MPa}$ at pretensioning. Test results indicated that more precise and reliable measurement on the transfer length was attained with FBG sensors than conventional gauges attached on concrete surface. Through comparing the measured transfer length and predictions, applicability of several transfer length models in literature was investigated. This paper can be useful for relevant research field such as investigation on the bond mechanism of a seven-wire strand in concrete members.
\end{abstract}

Keywords : smart tendon, FBG sensor, pretension, transfer length

\section{1. 서 론}

프리텐션 부재에서는 프리스트레스가 도입된 강연선의 힘 이 콘크리트로 전달되는 구간이 강연선 정착 단부로부터 발 생하게 되며, 정착 단부로부터 콘크리트에 유효 프리스트레 스가 발생하는 곳까지의 거리를 전달길이(transfer length) 라고 한다(ACI 318-11, 2011). 전달길이 구간 내에서는 강연선과 콘크리트 사이의 부착으로 인해 콘크리트에 도입되 는 유효 프리스트레스가 변화하게 되며, 따라서 프리텐션 부 재의 정착구 부근에서의 응력 분포를 예측하고 향후 프리텐 션 부재의 설계에 필수적으로 고려되어야 하는 강연선 정착 길이(development length)를 결정하는데 전달길이의 산정 은 매우 중요한 요인이다(Barnes et al., 2006).

프리텐션 부재에서의 전달길이를 측정하기 위해 데믹게이

\footnotetext{
${ }^{\dagger}$ Corresponding author:
}

Tel: +82-51-629-6073; E-mail: hwanwoo@pknu.ac.kr Received October 26 2015; Revised November 24 2015; Accepted November 252015

(C) 2015 by Computational Structural Engineering Institute of Korea
지, 콘크리트 표면 또는 강연선에 부착하는 전기저항식 게이지 등 많은 방법들이 여러 연구자들(Zia and Mostafa, 1977; Mitchel et al., 1993; Russell and Burns, 1997; Oh and Kim, 2000; Park et al., 2012)에 의해 시도되어 왔 다. 하지만, 데믹게이지의 경우 계측 결과의 신뢰성이 떨어지 고, 콘크리트 표면에 부착하는 게이지의 경우 시공 오차 등으 로 발생하는 부재의 편심에 의한 영향이 있으며, 강연선에 부 착하는 전기저항식 게이지의 경우 강연선 고유의 부착 성능이 게이지에 영향을 받아 전달길이가 실제와 달라질 우려가 있는 등 아직까지 확실한 전달길이 측정 방법이 개발되어 있지 않은 실정이다.

최근들어 강연선의 긴장력을 계측하기 위해 $\mathrm{FBG}$ 센서를 활 용한 기법이 활발히 연구되고 있다(Udd, 1996; Lau, 2003; Ren et al., 2005; Kim et al., 2008; 2010; 2012). FBG

This is an Open-Access article distributed under the terms of the Creative Commons Attribution Non-Commercial License(http://creativecommons. org/licenses/by-nc/3.0) which permits unrestricted non-commercial use, distribution, and reproduction in any medium, provided the original work is properly cited. 
센서를 활용할 경우 공용 중 강연선 긴장력을 손쉽게 계측할 수 있을 뿐만 아니라, 강연선의 전달길이 측정 시 표면 부착 매 립형 게이지와 달리 강연선과 콘크리트 계면에서의 부착 성능 에 전혀 영향을 미치지 않는 장점이 있다.

한편, 고강도 콘크리트 부재에서의 강연선 전달길이와 관 련하여 현행 설계기준(ACI 318-11, 2011)과 기존 이론 모 델들(Zia and Mostafa, 1977; Balazs, 1992; Mitchell et al., 1993; Park and Cho, 2014)과의 차이가 큰 것으 로 알려져 있다. 특히 현행 설계기준에서는 전달길이에 대한 콘크리트 강도의 효과가 반영되지 않아 추가 연구가 필요한 실정이다. 따라서, 본 연구에서는 FBG 센서를 활용하여 실 험을 통해 고강도 콘크리트 부재에서 강연선에 대한 전달길 이를 측정하고자 한다.

\section{2. 기존 강연선 전달길이 모델}

프리텐션 콘크리트 부재에 대해 ACI 318-11에서 제시하 고 있는 전달길이 산정식을 비롯하여 1970년대부터 최근까 지 여러 연구자들에 의해 제시된 주요 전달길이 모델들을 Table 1에 요약하였다. 표에서 보는 바와 같이 현재 설계에 적용되고 있는 $\mathrm{ACI} 318-11$ 이 제시하고 있는 전달길이 모델 에서는 강연선의 응력과 지름 등 두 가지 요소만 고려하고 콘크리트 압축강도의 영향이 고려되지 않은 반면 다른 연구 자들이 제시한 전달길이 모델에서는 콘크리트 압축강도의 영 향까지 추가하여 고려한 것을 확인할 수 있다. 비교를 보다 명확히 하기 위해 콘크리트 단면 $150 \times 150 \mathrm{~mm}$ 에 콘크리트 타설 후 10 일 뒤 $15.2 \mathrm{~mm}$ 강연선을 인장강도의 약 $60 \%$ 로 긴장한 가상의 프리텐션 부재를 대상으로 콘크리트 강도의 변화에 따라 기존의 모델들이 예측하는 강연선의 전달길이들

Table 1 Transfer length model for a pretensioned tendon

\begin{tabular}{|c|c|}
\hline Reference & $\begin{array}{c}\text { Transfer length model for a } \\
\text { pretensioned tendon }\end{array}$ \\
\hline ACI 318-11 & $L_{t}=\frac{f_{s e}}{21} d_{b}$ \\
\hline Zia and Mostafa, 1977 & $L_{t}=1.5 \frac{f_{s i} f_{c i}{ }^{\prime}}{f_{b}-116.84}$ \\
\hline Balázs, 1992 & $L_{t}=d_{b} K_{1} \sqrt[5]{\frac{f_{s e}^{3}}{f_{c i}{ }^{2}}}$ \\
\hline Mitchell et al., 1993 & $L_{t}=0.048 f_{n} d_{b} \sqrt{\frac{20}{f_{c i}{ }^{\prime}}}$ \\
\hline Park and Cho, 2014 & where $a_{1}=\frac{a_{0} \pi}{600} \frac{f_{c i}{ }^{\prime}}{E_{p} A_{p}} \frac{\epsilon_{p r}}{\epsilon_{p r}-\epsilon_{e l}}$, \\
$a_{0}=1.0, a_{2}=\frac{\pi d_{p}}{E_{p} A_{p}{ }^{2}-4 a_{1}\left(a_{3}-\epsilon_{p r}\right)}$
\end{tabular}

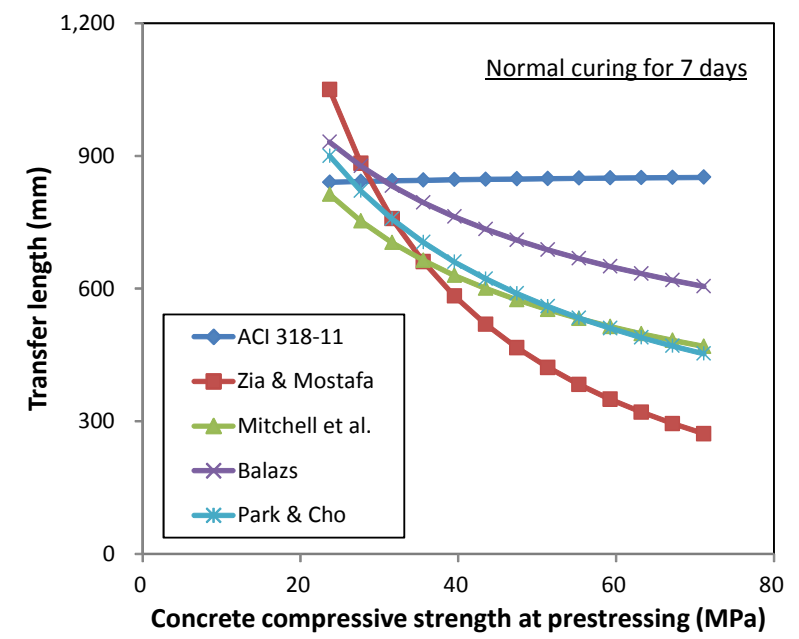

Fig. 1 Comparison of transfer length models for a seven-wire strand

을 Fig. 1에 나타내었다. 참고로 고려된 재령에 따른 콘크리 트의 압축강도 및 탄성계수의 발현은 콘크리트 구조기준 (2012)에 제시된 일반 양생의 경우를 참조하였다. 그림에서 보는 바와 같이 ACI 318-11의 경우 콘크리트 압축강도가 증가하더라도 전달길이가 $850 \mathrm{~mm}$ 내외로 거의 일정하게 예 측되는 반면 다른 모델들의 경우 콘크리트 압축강도가 증가 할수록 전달길이가 급격히 감소하는 것으로 예측되었다. 또 한, 긴장 시 콘크리트 압축강도가 $40 \mathrm{MPa}$ 이상으로 고강도 일 경우 기존 연구자들이 제시한 모델들이 예측한 전달길이 에서 편차가 상당히 큰 것으로 나타났다. 따라서, 교량 및 고 층 건물 등에 적용되는 콘크리트의 압축강도가 점점 증가하 는 추세를 고려할 때, 고강도 콘크리트를 적용한 프리텐션 부재에서의 강연선 전달길이에 대한 추가 연구가 필요한 것 으로 판단된다.

\section{3. $\mathrm{FBG}$ 를 이용한 강연선 전달길이 측정 실험}

\section{1 실험 개요}

고강도 콘크리트 부재에서의 강연선 전달길이 측정을 위해 Fig. 2에서 보는 바와 같이 콘크리트 단면 $150 \times 150 \mathrm{~mm}$, 길이 $3,000 \mathrm{~mm}$ 인 시험체를 총 5 개를 제작하였으며, 각 시 험체의 단면 가운데에 $\mathrm{FBG}$ 센서가 기입된 $15.2 \mathrm{~mm}$ 스마트

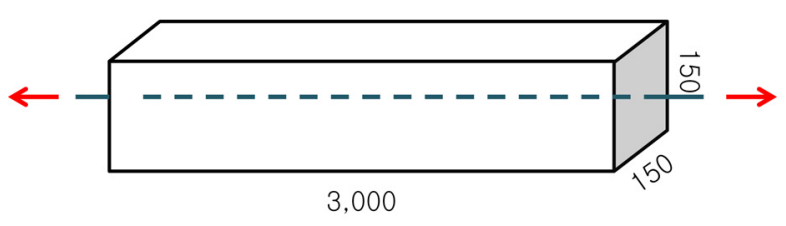

Fig. 2 Dimension of the specimen 


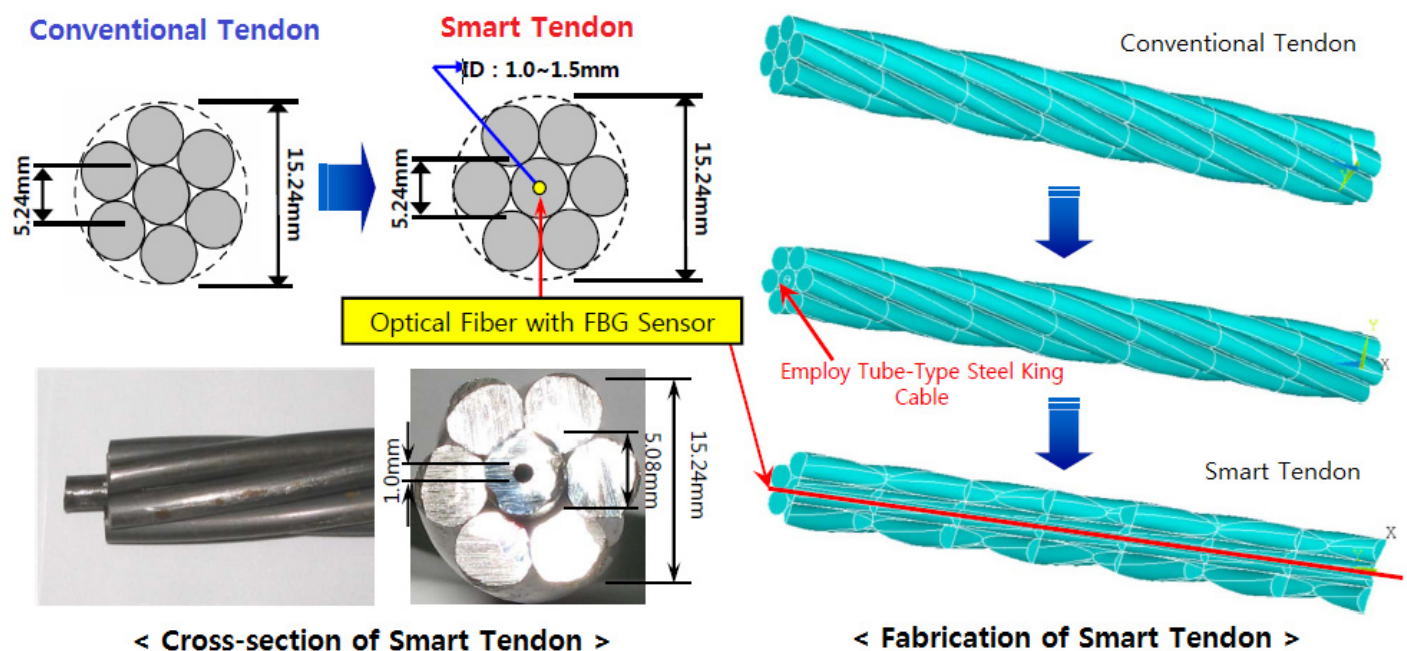

Fig. 3 Seven-wire strand with FBG sensors

강연선 1 가닥을 배치하였다.

기존 설계기준 및 문헌들에서 고강도 콘크리트 부재에서의 전달길이가 크게 다르게 예측되는 것으로 나타났으므로, 본 연구에서는 28 일 공칭강도가 $60 \mathrm{MPa}$ 인 고강도 콘크리트를 사용하였다. 실제 프리텐션은 콘크리트 재령 12 일에 도입하 였으며, 이 때 $\phi 150 \times 300 \mathrm{~mm}$ 원형 공시체 3 개에 대한 압축 강도 실험으로부터 콘크리트의 압축강도는 $58 \mathrm{MPa}$ 로 측정되 었다.

한편, 본 연구에서 사용된 $\mathrm{FBG}$ 센서가 기입된 스마트 강 연선은 Fig. 3에서 보는 바와 같이 일반 강연선과 달리 강연 선 가운데 킹 와이어 내부에 $\mathrm{FBG}$ 센서가 기입된 광섬유를 넣은 것으로서, 제작의 용이함 및 $\mathrm{FBG}$ 센서 성능 확보 등을 위해 킹 와이어 재질이 일반 강선과 다른 seamless steel tube로 되어있다. Fig. 4에서 보는 바와 같이 Seamless steel tube의 경우 항복 강도가 일반 강선의 약 $1,700 \mathrm{MPa}$ 보다 낮은 약 $400 \mathrm{MPa}$ 인 것으로 측정되었으며, 이에 따라 스마트 강연선의 탄성계수는 일반 강연선보다 작게 된다. 본

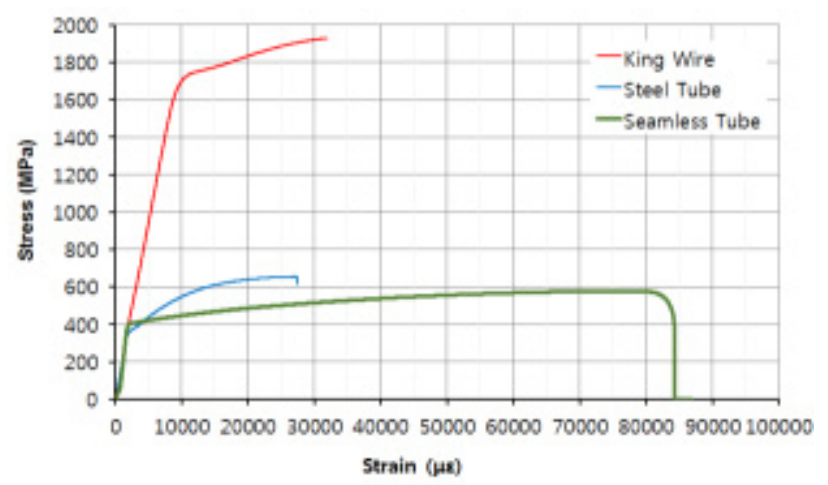

Fig. 4 Stress-strain curves for a king wire, steel tube, and seamless tube
연구에서 사용된 스마트 강연선의 경우 프리텐션 실험 시 측 정된 하중과 변형률을 바탕으로 산정한 결과 탄성계수가 $138,160 \mathrm{MPa}$ 으로 나타났다.

시험체 제작을 위해 우선 강재로 이루어진 반력대를 조립 및 설치하였으며, 반력대 사이에 시험체 거푸집을 제작하였 다. 거푸집 제작 후 강연선을 거푸집에 종방향으로 관통하도 록 배치한 뒤 강연선을 긴장 및 반력대에 정착하였다. 강연 선 긴장 시 강연선에 도입된 긴장력을 측정하기 위해 반력대 정착구에 로드셀을 설치하였으며, 시험체 중 하나인 S2 시험 체에 대해 로드셀을 이용해 측정된 강연선의 긴장력은 $108.4 \mathrm{kN}$ 으로 나타났다. 이는 변형률 0.005657 에 해당하는 것으로서 $1,925 \mathrm{MPa}$ 의 인장강도를 가지는 일반 강연선의 인 장강도 $65 \%$ 에 해당하는 변형률이다. 강연선 긴장 후 콘크리 트를 타설하였으며, 충분한 강도 발현을 위해 12 일 동안 야 외에서 일반 양생하였으며 긴장된 강연선을 절단함으로써 프 리텐션을 콘크리트 시험체에 도입하였다.

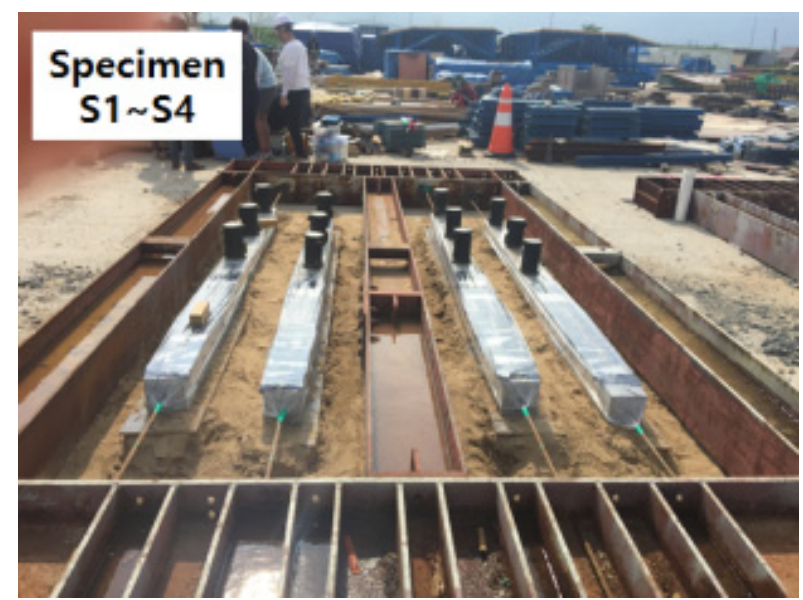

Fig. 5 Steel test frame and the specimens(S1-S4) 
Fig. 5는 프리텐션 도입 전 반력대 및 시험체의 배치 모 습을 보여주는 것이다.

\section{2 계측 센서}

프리텐션 도입 시 콘크리트와 강연선의 부착으로 인한 전 달길이 구간에서의 강연선 및 콘크리트의 변형률의 변화를 측정하기 위해 부재 단부로부터 거리를 달리하여 총 8개 지 점에 대해 $\mathrm{FBG}$ 센서를 기입하였다. 이 때, 기존 모델들에 의해 전달길이 구간으로 예상되는 지점에 보다 많은 $\mathrm{FBG}$ 센서를 기입하였다. 또한, 강연선에 긴장을 도입할 때와 강연 선 절단을 통한 콘크리트 부재로의 프리텐션 도입 이후의 강 연선 변형률을 측정하기 위해 시험체 바깥에 노출된 강연선 부위에 대해 $\mathrm{FBG}$ 센서 1개를 추가로 기입하였다.

이와 더불어 강연선의 변형률과 콘크리트 변형률을 비교하 기 위해 $\mathrm{FBG}$ 센서가 기입된 8개 지점에 콘크리트 게이지를 시험체 표면에 부착하였다. 이 때, 시험 중 프리텐션 도입 시 발생 가능한 프리스트레스 편심의 영향을 보정하기 위해 1 개 지점마다 시험체 단면의 좌우 및 상면 중앙에 각 1 개의 콘크 리트 게이지를 부착하였다.

또한, 제한된 계측 센서를 효율적으로 사용하기 위해 프리
텐션 도입 시 강연선 절단에 따른 동적 영향이 상대적으로 작을 것으로 예상되는 부분, 즉 강연선 절단이 이루어지는 반대편에 $\mathrm{FBG}$ 센서 및 콘크리트 게이지를 배치하였다. Fig. 6 은 시험체에 배치된 $\mathrm{FBG}$ 센서와 콘크리트 게이지의 위치를 나타낸 것이다.

\section{3 실험 결과}

\subsubsection{FBG 센서 측정 결과}

프리텐션 도입으로 인해 콘크리트 및 강연선에 발생하는 변형률을 각각 Fig. 7 및 Fig. 8에 나타내었다. 여기에서, Fig. 7에서의 콘크리트의 변형률은 콘크리트 표면 게이지로 부터 측정된 결과이며, Fig. 8에 나타낸 변형률은 FBG 센 서로부터 측정된 것으로서 프리텐션 도입으로 인해 강연선의 변형률에서의 변화값을 나타낸 것이다. 즉, 프리텐션 도입 이 후 강연선의 실제 변형률은 Fig. 8에서의 시험체 끝단부의 변형률에 $\mathrm{FBG}$ 센서로부터 측정된 변형률을 제거하면 된다. 참고로 총 5 개의 시험체 중 4 개의 시험체에서 콘크리트 양생 기간 중 $\mathrm{FBG}$ 센서 일부가 손실되었으며, 따라서 본 연구에 서는 1 개의 시험체 $(\mathrm{S} 2)$ 에 대해 $\mathrm{FBG}$ 센서 계측 결과를 정리 하였다.

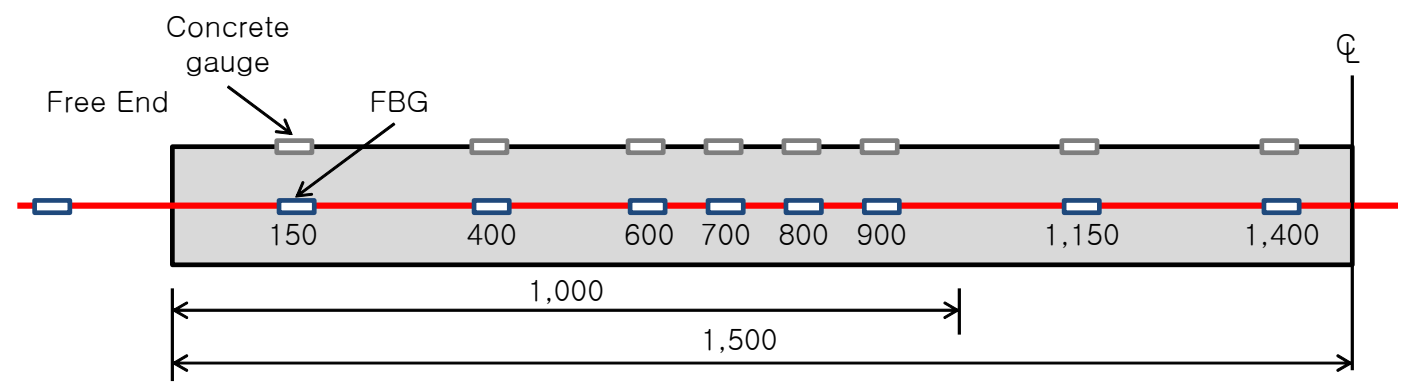

Fig. 6 Locations of FBG sensors and concrete strain gauges

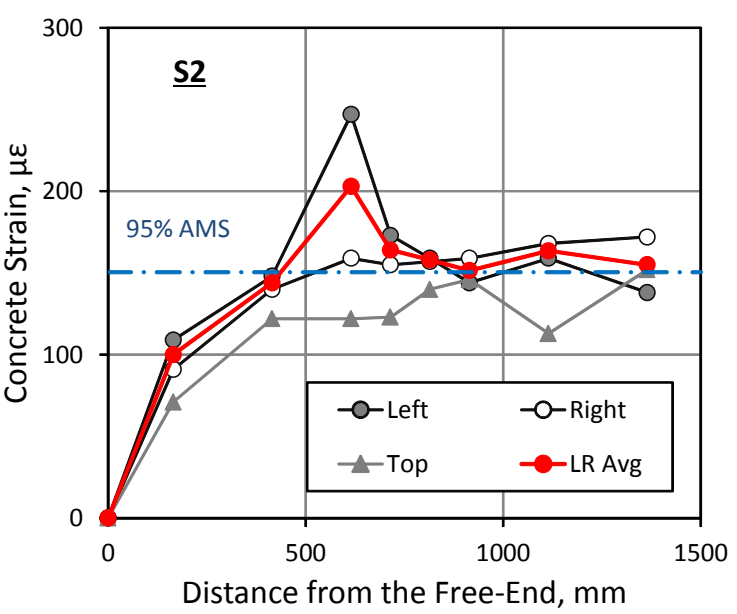

Fig. 7 Concrete strain profile - S2 specimen

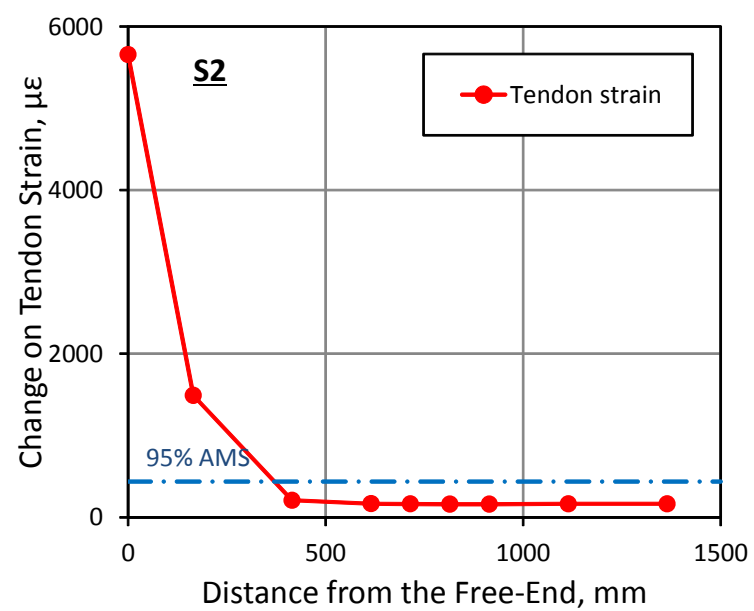

Fig. 8 Tendon strain profile - S2 specimen 

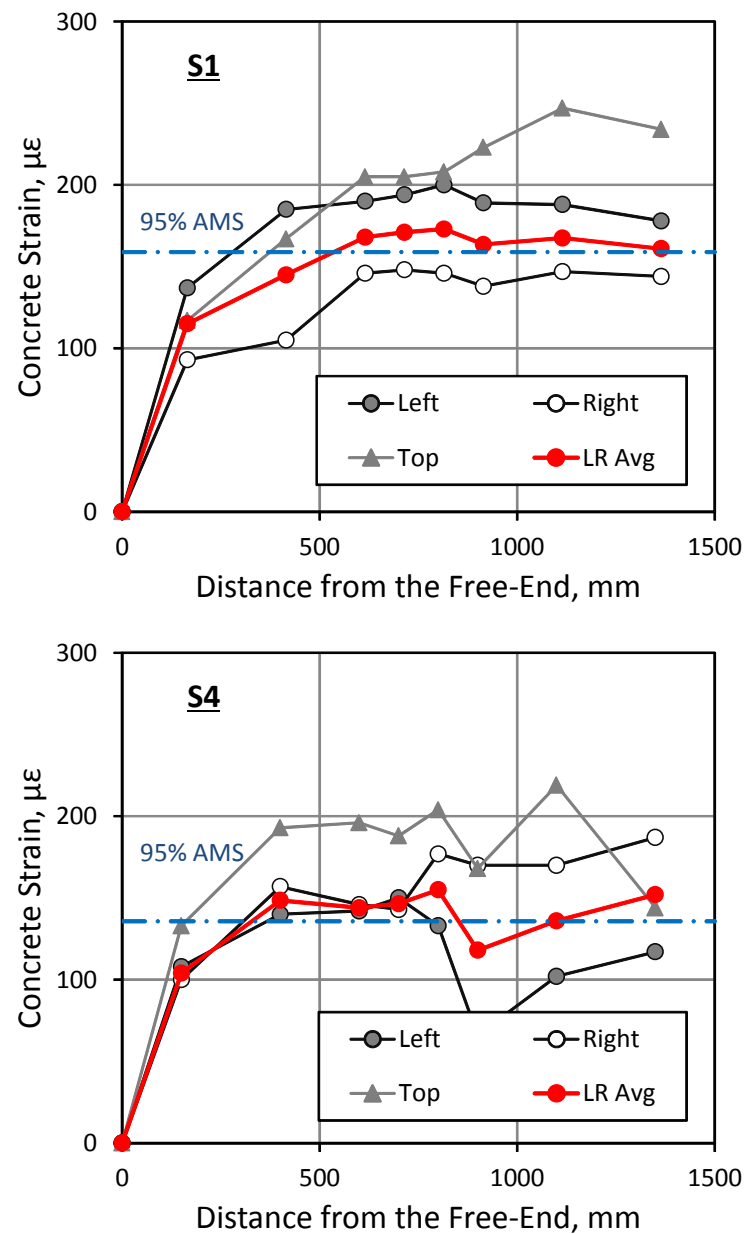

Fig. 9 Concrete strain profiles
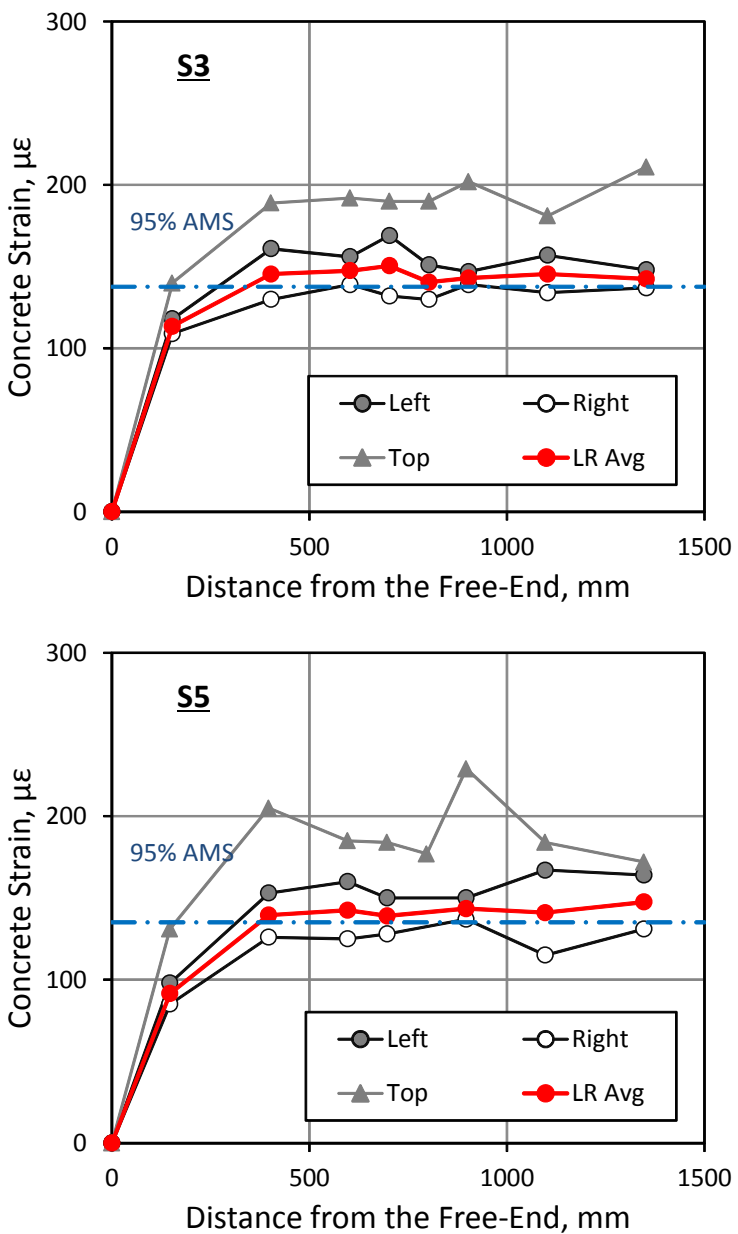

S1, S3, S4, S5 specimens

인해 일반적인 경향에서 크게 벗어난 것으로 판단되어 전달 길이 산정에서 제외하였다. 그림에서 보는 바와 같이 콘크리 트 및 강연선의 변형률로부터 전달길이를 산정한 결과 각각 $512 \mathrm{~mm}$ 와 $565 \mathrm{~mm}$ 로서 비슷하게 나타났다. 다만, FBG 센 서 계측 결과와 달리 전달길이 구간 밖에서 콘크리트 게이지 계측 결과에 편차가 발생하였으며 이에 따라 전달 길이 산정 에 실험 계측 오차가 있는 것으로 판단된다. 따라서 $\mathrm{FBG}$ 센 서를 활용할 경우 실험 결과로부터 보다 정밀한 전달길이 산 정이 가능한 것으로 판단된다.

한편, $\mathrm{FBG}$ 센서를 활용할 경우 콘크리트 표면 게이지로 부터 측정된 결과보다 훨씬 안정적인 결과를 확보할 수 있었 으며, 계측의 편이성 및 일반적인 건설현장 관리 상황 등을 고려할 때 $\mathrm{FBG}$ 센서의 현장 적용성이 콘크리트 표면 게이 지보다 더욱 뛰어난 것으로 판단된다.

\subsection{2 콘크리트 표면 게이지 측정 결과}

프리텐션된 고강도 콘크리트에서의 강연선 전달길이를 산 정하기 위해 $\mathrm{S} 2$ 시험체를 제외한 나머지 4 개의 시험체에서 
콘크리트 표면 게이지로부터 계측된 결과를 Fig. 9에 나타내 었다. 참고로 $\mathrm{S} 2$ 시험체를 제외한 나머지 시험체들의 경우 콘크리트 양생 기간 동안 $\mathrm{FBG}$ 센서가 손실되었으며, 콘크리 트 게이지 계측 결과만을 전달길이 산정에 활용하였다.

그림에서 보는 바와 같이 콘크리트 표면에 부착된 게이지 로부터 측정된 콘크리트의 변형률 분포는 S2 부재와 전반적 으로 비슷한 양상을 보였다. 즉, 전달길이로 추정되는 구간 내에서는 콘크리트의 변형률이 시험체 끝단부에서 거리가 멀 어질수록 점점 증가하는 것으로 나타났다. $\mathrm{S} 2$ 시험체와 마찬 가지로 $95 \% \mathrm{AMS}$ 방법을 사용하여 전달길이를 산정한 결과 $\mathrm{S} 1, \mathrm{~S} 3, \mathrm{~S} 4, \mathrm{~S} 5$ 시험체에 대해 각각 $536,343,328$, $374 \mathrm{~mm}$ 로 나타났다. $\mathrm{S} 1$ 및 $\mathrm{S} 2$ 시험체에서 상대적으로 다 른 시험체에 비해 전달길이가 크게 산정된 것은 $\mathrm{S} 1$ 및 $\mathrm{S} 2$ 시험체가 다른 시험체들보다 큰 프리스트레스가 가해진 것이 주요 원인으로 판단되며, 이는 전달길이 구간 밖에서의 콘크 리트 평균 변형률이 S1 및 S2 시험체에서 다른 시험체들보 다 크게 측정된 것으로 확인할 수 있다.

한편, 콘크리트 표면에 부착된 게이지로부터 측정된 결과 는 프리텐션 부재에서의 전형적인 변형률 분포를 전반적으로 보여주고 있으나, 측정된 변형률들이 $\mathrm{FBG}$ 에 비해 상대적으 로 안정적이지 못한 것으로 나타났다. 전달길이 구간 밖인 유효 프리스트레스가 도입되는 구간에서의 각 측정 위치별 변형률을 비교했을 때 $\mathrm{S} 2$ 시험체에서의 FBG 센서 계측 결 과가 최대 $6 \times 10^{-6}$ 의 차이를 나타낸 반면 시험체 좌우면에 부 착된 콘크리트 게이지로부터 계측된 변형률은 $\mathrm{S} 4$ 시험체에서 최대 $37 \times 10^{-6}$ 의 차이가 나타났다. 따라서, 기존의 콘크리트 표면에 부착하는 전기 저항식 게이지보다 FBG 센서가 보다 높은 계측의 정밀성 및 신뢰성을 보여주는 것으로 판단된다.

\section{4. 실험 결과와 기존 모델들과의 비교}

본 연구에서 수행된 실험으로부터 계측된 전달길이와 Table 1 에 정리되어 있는 기존 모델들이 예측하는 전달길이 를 비교한 것을 Fig. 10에 나타내었다. 참고로 본 비교에서 는 여러 시험체들의 결과값을 활용하기 위해 콘크리트 표면 에 부착된 게이지로부터 산정된 전달길이들을 기존 모델들의 예측값과 비교에 사용하였다. 또한, 기존 모델들을 이용한 전 달길이 계산 시 각 시험체별로 실제 도입된 긴장력과 $\mathrm{FBG}$ 센서가 기입된 스마트 강연선의 탄성계수를 고려하였다.

그림에서 보는 바와 같이 Zia와 Mostafa(1977) 및 Mitchell 등(1993)이 제안한 전달길이 예측식은 실험에서 측정된 전달길이보다 작게 예측하는 것으로 나타난 반면 ACI 319-11(2011) 및 Balázs(1992)가 제안한 전달길이

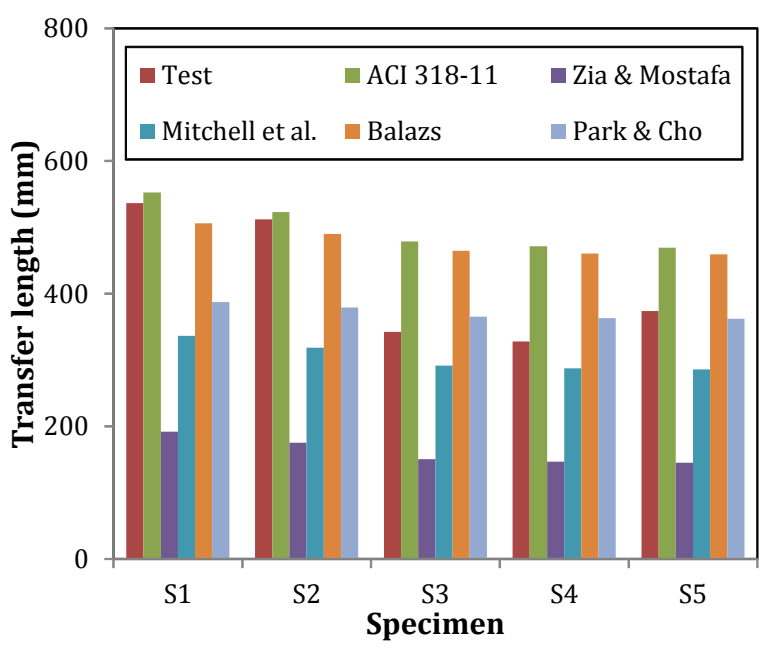

Fig. 10 Comparison of the measured transfer length with the model predictions

예측식은 전달길이가 비교적 크게 측정된 S1과 S2 시험체에 대해 실험 결과와 비슷하게 전달길이를 예측하였으나 전달길 이가 비교적 작게 측정된 나머지 시험체에 대해서는 전달길 이를 측정값보다 크게 예측하는 것으로 나타났다. 또한, Park과 Cho(2014)의 경우 S1 및 S2 시험체에 대해서는 전달길이를 작게 예측한 반면 나머지 시험체에 대해서는 실 험값과 비슷하게 전달길이를 예측하는 것으로 나타났다. 이 와 같이 고강도 콘크리트 부재에서의 강연선 전달길이를 예 상하는데 있어 기존 모델들이 시험체에 따라 예측 정확성이 많이 달라지는 것은 Park과 $\mathrm{Cho}$ (2014)의 실험결과 분석 에서 나타났듯이 실제 시험체 별로 강연선의 부착 성능이 크 게 달라질 수 있기 때문인 것으로 사료된다. 본 연구에서의 실험 결과, 강연선의 부착 성능이 $\mathrm{S} 1$ 및 $\mathrm{S} 2$ 시험체와 나머 지 시험체들 등 크게 두 그룹으로 분류되는 것으로 나타났 다. Park과 $\mathrm{Cho}$ (2014)의 전달길이 분석에서 부착성능 손 실이 발생되지 않은 시험체들만을 대상으로 전달길이 모델 유도 및 검증이 이루어진 것을 토대로, 부착성능 손실이 발 생되지 않은 시험체 $\mathrm{S} 3 \sim \mathrm{S} 4$ 에서 측정된 전달길이가 $\mathrm{ACI}$ 318-11(2011)의 예측값보다 훨씬 작은 것으로 볼 때, 콘크 리트 강도가 증가할수록 강연선 전달길이가 감소하는 것으로 판단할 수 있다. 다만, 강연선의 부착 성능이 시험체별로 편 차가 큰 것으로 나타났으므로 일반적인 강연선의 부착 성능 을 확인하기 위해 추가 연구가 필요한 것으로 판단된다.

\section{5. 결 론}

본 연구에서는 고강도 콘크리트 부재에서의 강연선 전달길 이를 측정하기 위해 $\mathrm{FBG}$ 센서가 기입된 스마트 강연선을 사용하여 총 5 개의 시험체를 제작한 후 프리텐션 도입에 따 
른 강연선의 전달길이를 측정하였다. 본 연구결과 도출된 결 론을 요약하면 다음과 같다.

(1) FBG 센서를 통해 계측된 강연선의 전달길이는 콘크 리트 표면에 부착된 게이지로부터 측정된 전달길이와 경향이 매우 유사한 것으로 확인되었다.

(2) 유효 프리스트레스가 도입되는 전달길이 이외의 구간 에 대해 계측된 변형률을 분석한 결과 $\mathrm{FBG}$ 센서 계 측 결과가 최대 $6 \times 10^{-6}$ 의 차이를 나타낸 반면 시험체 좌우면에 부착된 콘크리트 게이지로부터 계측된 변형 률은 평균값을 적용하더라도 최대 $37 \times 10^{-6}$ 의 차이가 나타났다.

(3) 실험 결과 프리텐션 부재의 강연선 전달길이 측정 시 기존의 콘크리트 표면에 부착하는 전기 저항식 게이 지보다 FBG 센서가 보다 높은 계측의 정밀성 및 신 뢰성을 보여주는 것으로 판단된다.

(4) 계측의 편이성 및 일반적인 건설 현장 관리 상황 등 을 고려할 때 $\mathrm{FBG}$ 센서의 현장 적용성이 기존의 콘크 리트 표면 게이지보다 더욱 뛰어난 것으로 판단된다.

(5) 총 5 개의 시험체 중 4 개의 시험체에서 양생 중 $\mathrm{FBG}$ 센서가 손실되었다. 따라서, $\mathrm{FBG}$ 센서 내구성 향상 을 위한 기술 개발이 필요한 것으로 나타났다.

(6) 본 연구 내용은 FBG 센서로부터 계측된 결과를 바탕 으로 강연선과 콘크리트 계면에서의 부착 특성 분석 및 일반 강연선에서의 전달길이 측정 산정을 위한 알 고리즘 개발 등을 통해 관련 분야 연구 등에 유용할 것으로 기대된다.

\section{감사의 글}

본 연구는 국토교통부 국토교통기술촉진연구사업의 연구비 지원(과제번호\#15CTAP-C078424-02)에 의해 수행되었습 니다. 아울러 시험체 제작에 도움을 주신 성환이앤씨, 대우건 설 및 한국도로공사에 감사드립니다.

\section{References}

ACI Committee 318 (2011) Building Code Requirements for Structural Concrete (ACI 318-11) and Commentary, American Concrete Institute, Farmington Hills, MI, USA.

Balázs, G.L. (1992) Transfer Control of Prestressing Strands, PCI J., 37, pp.60 71.

Barnes, R.W., Grove, J.W., Burns, N.H. (2006) Experimental Assessment of Factors Affecting
Transfer Length, ACI Struct. J., 100, pp.740 748.

Kim, J.M., Kim, H.W., Kim, Y.S., Kim, J.W., Yun, C.B. (2008) A Methodology for Monitoring Prestressed Force of Bridges Using OFS-embedded Stand, J. Comput. Struct. Eng. Inst. Korea, 21(3), pp. 287 294.

Kim, J.M., Kim, H.W., Park, Y.H., Kim, Y.S. (2010) Tension Monitoring of a Prestressing Strand for Concrete Bridge using In-Tendon FBG Sensors, Proc. IABMAS-2010, pp.205 210.

Kim, J.M., Kim, H.W., Park, Y.H., Yang, I.H., Kim, Y.S. (2012) FBG Sensors Encapsulated into 7-Wire Steel Strand for Tension Monitoring of a Prestressing Tendon, Adv. Struct. Eng., 15(6), pp. 907 918.

Lau, K.T. (2003) Fibre-Optic Sensors and Smart Composites for Concrete Applications, Mag. Concr. Res., 55(1), pp.19 34.

Ministry of Land, Transport and Maritime Affairs (2012) The Revision of Structural Concrete Design Code, p.342

Mitchell, D., Cook, W.D., Khan, A.A., Tham, T. (1993) Influence of High Strength Concrete on Transfer and Development Length of Prestressing Strand, PCI J., 38, pp.52 66.

Oh, B.H., Kim, E.S. (2000) Realistic Evaluation of Transfer Lengths in Pretensioned, Prestressed Concrete Members, ACI Struct. J., 97, pp.821 830.

Park, H., Cho, J.-Y. (2014) Bond-Slip-Strain Relationship in Transfer Zone of Pretensioned Concrete Elements, ACI Struct. J., 111, pp.503 513.

Park, H., Din, Z.U., Cho, J.-Y. (2012) Methodological Aspects in the Measurement of Strand Transfer Length in Pretensioned Concrete, ACI Struct. J., 109, pp.625 634.

Ren, L., Li, H.N., Sun, L., Li, D.S. (2005) Development of Tube-Packaged FBG Strain Sensor and Application in the Vibration Experiment of Submarine Pipeline Model. SPIE Proc., pp.98 103.

Russell, B.W., Burns, N.H. (1993) Design Guidelines for Transfer, Development and Debonding of Large Diameter Seven Wire Strands in Pretensioned Concrete Gierders, FHWA/TX-93+1210-5F, Cener for Transportation Research, the University of Texas 
$\mathrm{FBG}$ 센서를 이용한 강연선 전달길이 측정

at Austin, Austin, TX, USA, 200.

Russell, B.W., Burns, N.H. (1997) Measurement of Transfer Lengths on Pretensioned Concrete Elements, J. Struct. Eng., ASCE, 123, pp.541 549.
Udd, E. (1996) Fiber Optic Smart Structures, John Wiley and Sons, Inc.

Zia, P., Mostafa, T. (1977) Development Length of Prestressing Strands, PCI J., 22, pp.54 65.

본 논문에서는 프리텐션된 고강도 콘크리트 부재에서의 전달길이를 측정하기 위해 FBG 센서가 기입된 스마트 강연선을 활용하여 실험을 수행하였다. 전달길이 측정을 위해 길이 $3 \mathrm{~m}$, 단면 $150 \times 150 \mathrm{~mm}$ 의 고강도 콘크리트 시험체를 총 5 개 제작하 였으며, 프리텐션 도입 시 콘크리트 압축강도는 $58 \mathrm{MPa}$ 로 측정되었다. 실험 결과 콘크리트 표면에 부착하는 기존의 전기 저 항식 게이지보다 $\mathrm{FBG}$ 센서로부터 보다 정밀하고 신뢰성있는 강연선의 전달길이를 계측할 수 있는 것으로 나타났다. 계측 결과로부터 산정된 강연선 전달길이를 기존의 여러 모델들과 비교하였으며, 이를 통해 고강도 콘크리트 부재에서의 전달길 이 산정에 대한 기존 모델들의 적용성을 분석하였다. 본 연구 내용은 향후 강연선의 부착 특성 분석 등의 관련 분야 연구 등 에 유용할 것으로 기대된다.

핵심용어 : 스마트 강연선, $\mathrm{FBG}$ 센서, 프리텐션, 전달길이 